\title{
PEMBERDAYAAN MASYARAKAT PASCA KEAKSARAAN FUNGSIONAL MELALUI KELOMPOK BELAJAR USAHA UNTUK MENINGKATKAN TARAF HIDUP
}

\author{
Agus Winarti \\ e-mail: aguswinarti56@gmail.com \\ Pendidikan Luar Sekolah Universitas Bandung Raya \\ Jalan Banten No. 11 Bandung, 40272
}

\begin{abstract}
Abstrak: Tujuan penelitian ini adalah untuk memberdayakan masyarakat pasca keaksaraan fungsional (KF) melalui kelompok belajar usaha di Desa Cimenyan, Kecamatan Cimenyan Kabupaten Bandung. Penelitian ini dilaksanakan dari bulan Maret sampai dengan Mei 2015 dengan mewawancarai 20 orang perempuan dengan latar belakang pekerjaan bervariasi (buruh tani, buruh serabutan dan ibu rumah tangga). Narasumber adalah masyarakat pasca keaksaraan fungsional yang tergabung dalam Kelompok Belajar Usaha. Data yang terkumpul dianalisis secara kualitatif dan disimpulkan. Hasil penelitian menunjukkan, dengan dibentuknya Kelompok Belajar Berusaha (KBU) masyarakat memiliki keberdayaan dengan usaha kelompok (satu kelompok 5 orang) serta pendapatan dan taraf hidup meningkat.

Kata-kata kunci: Kelompok Belajar Usaha (KBU), Keaksaraan Fungsional (KF), pemberdayaan masyarakat, taraf hidup.
\end{abstract}

\section{COMMUNITY EMPOWERMENT POST FUNCTIONAL LITERACY THROUGH BUSINESS LEARNING GROUP TO IMPROVE LIFE QUALITY}

\begin{abstract}
The purpose of this study was to empower the community of post functional literacy through business study groups in Cimenyan village, Cimenyan Subdistrict, Bandung District. The research was conducted as from March through May 2015, and the data were collected by interviewing 20 resource persons with various professional backgrounds. The data were analyzed qualitatively to draw conclusion. The result of the study indicates, the formation of Business Study Groups (KBU) empowers the community to develop their business and improves their incomes and raises their living standards.
\end{abstract}

Keywords: Business Study Groups, functional literacy, community empowerment, living standards.

\section{PENDAHULUAN}

Pemberdayaan masyarakat adalah suatu proses yang membangun manusia atau masyarakat melalui pengembangan kemampuan masyarakat, perubahan perilaku masyarakat, dan pengaturan masyarakat. Tujuan utama dalam pemberdayaan masyarakat yaitu mengembangkan kemampuan masyarakat, mengubah perilaku masyarakat, dan mengatur masyarakat. Pemberdayaan masyarakat sebuah konsep pembangunan ekonomi termasuk nilai-nilai sosial dan dimungkinkan pula penanaman nilai-nilai budaya maju; seperti kerja keras, hemat, keterbukaan dan kebertanggung jawaban. Proses pemberdayaan seperti ini merupakan paradigma baru dalam pembangunan manusia seutuhnya dan berkelanjutan.

Pemberdayaan masyarakat pascakeaksaraan fungsional adalah upaya meningkatkan kemampuan masyarakat dalam bidang pengetahuan, sikap dan keterampilan, sehingga masyarakat mampu menunjukkan eksistensinya dan dapat berpartisipasi serta memperbaiki kedudukannya dalam masyarakat. Proses partisipatif yang berkelanjutan di mana anggota masyarakat bekerja sama dalam kelompok belajar berusaha, berbagi pengetahuan dan pengalaman serta adanya perubahan sikap berusaha untuk mencapai tujuan bersama.

Program pemberantasan buta aksara dalam beberapa tahun terakhir menunjukkan adanya peningkatan, baik dari segi jumlah anggaran yang diluncurkan, maupun dari segi jumlah capaian warga belajar yang dilibatkan dalam 
program pembelajaran. Penduduk buta aksara di Indonesia pada tahun 2012 usia 15 - 59 tahun berjumlah 6.401 .522 orang. Dari jumlah tersebut sebagian besar tinggal di daerah pedesaan seperti buruh tani, buruh serabutan, nela-yan dan kelompok masyarakat miskin perkotaan yaitu buruh berpenghasilan rendah atau penganggur yang pada umumnya adalah kaum urban. Mereka tertinggal dalam hal pengetahuan, keterampilan dan sikap mental inovatif dan pembangunan. Akibatnya, akses terhadap informasi dan komunikasi yang mendukung untuk memperoleh gambaran kehidupan yang lebih luas sangat terbatas karena mereka tidak memiliki kemampuan keaksaraan yang memadai.

Penuntasan keaksaraan fungsional merupakan kewajiban semua pihak dalam peningkatan Indek Pembangunan Masyarakat (IPM), masyarakat buta aksara sangat membutuhkan sentuhan pendidikan. Program pemberantasan buta aksara dalam beberapa tahun terakhir menunjukkan adanya peningkatan, baik dari segi jumlah anggaran yang diluncurkan, maupun dari segi jumlah capaian warga belajar yang dilibatkan dalam program pembelajaran.

Seperti diketahui, bahwa data BPS Provinsi Jawa Barat angka buta huruf menunjukan berkisar $3.82 \%-4.04 \%$ untuk usia di atas 10 tahun ke atas sekitar 3,38\% pada tahun $2010,3,62 \%$ pada tahun 2011 terjadi penurunan, hanya saja pada tahun 2012 terjadi kenaikan lagi justru melebihi pada tahun 2010 yaitu 3,39\%. Sedangkan pada tahun 2013 ada penurunan yaitu 2,95\%, persentase tersebut menurun walaupun hanya sedikit tiap tahunnya. (Sumber: BPS-RI, Susenas 2012).

Keberhasilan yang dicapai dalam perluasan akses pendidikan keaksaraan sesungguhnya merupakan bentuk usaha yang seharusnya dihargai. Keberhasilan penyelenggaraan keaksaraan fungsional memang menunjukkan hasil, dengan semakin menurunnya persentase jumlah buta aksara setiap tahunnya. Akan tetapi dari segi keberlanjutan keaksaraan fungsional ini belum ada tindak lanjut, kemanfaatan bagi masyarakat dirasakan kurang. Akibatnya ada sebagian masyarakat yang telah memperoleh SUKMA (surat keterangan melek aksara) kembali mejadi buta huruf.

Kelompok Belajar Usaha (KBU) diharapkan dapat memberikan manfaat yang positif dan memberikan pengaruh yang signifikan bagi peningkatan keterampilan kerja yang dapat memperluas peluang bagi masyarakat pasca KF di Desa Cimenyan. Pemberdayaan masyarakat pasca KF melalui KBU diharapkan dapat meningkatkan taraf hidup.

Mengacu dari latar belakang di atas maka dapat dirumuskan permasalahan penelitian yaitu bagaimana pemberdayaan masyarakat pasca keaksaraan fungsional melalui kelompok belajar usaha untuk meningkatkan taraf hidup. Secara umum penelitian ini bertujuan untuk memberdayakan masyarakat pasca keaksaraan fungsional melalui kelompok belajar usaha untuk meningkatkan taraf hidup di Desa Cimenyan, Kecamatan Cimenyan Kabupaten Bandung.

Untuk mencapai tujuan umum tersebut, secara khusus dirinci ke dalam pertanyaan penelitian sebagai berikut: (a) untuk memperoleh gambaran pemberdayaan masyarakat pasca keaksaraan fungsional melalui KBU untuk meningkatkan taraf hidup, (b) mendeskripsikan ketercapaian pemberdayaan masyarakat pasca keaksaraan fungsional melalui KBU untuk meningkatkan taraf hidup, (c) menganalisis dan mendeskripsikan dampak pemberdayaan masyarakat pasca keaksaraan fungsional melalui KBU untuk meningkatkan taraf hidup.

Hasil penelitian ini diharapkan dapat bermanfaat dalam hal sebagai berikut: (1) Penyelenggaraan pendidikan masyarakat, penelitian ini diharapkan dapat dijadikan sebagai acuan dalam langkah konkret dan strategi untuk pemberdayaan masyarakat pasca keaksaraan fungsional, (2) Pengambil kebijakan pendidikan di tingkat kabupaten, penelitian ini memberikan rekomendasi melalui data empirik terhadap perbaikan sistem memberdayakan masyarakat, ikut meningkatkan kemandirian masyarakat dan peningkatan taraf hidup masyarakat, (3) sebagai bahan pertimbangan bagi birokrat setingkat pemerintah Desa, Kecamatam maupun Kabupaten dan penelitian ini diharapkan dapat memicu pembentukan kelompok-kelompok belajar usaha untuk pemberdayaan masyarakat dalam rangka peran serta mereka di bidang pembangunan desanya.

Secara konseptual, pemberdayaan (empo- 
werment) memiliki pengertian menunjuk kepada kemampuan seseorang, khususnya kelompok rentan atau lemah sehingga mereka memiliki kekuatan atau kemampuan dalam: (1) memenuhi kebutuhan dasarnya sehingga mereka memiliki kebebasan (freedom) dalam arti bukan hanya bebas mengemukakan pendapat, melainkan bebas dari kelaparan, bebas dari kebodohan, bebas dari kesakitan, (2) menjangkau sumbersumber produktif yang memungkinkan mereka dapat meningkatkan pendapatannya, (3) mampu berpartisipasi dalam proses pembangunan dan keputusan-keputusan yang mempengaruhi mereka (Suharto, 2010).

Strategi pemberdayaan menurut (Ife; 2008) ada tiga strategi dasar pemberdayaan yaitu: (1) Pemberdayaan melalui kebijakan dan perencanaan, dilakukan dengan mengubah struktur dan lembaga-lembaga yang ada agar terjadi akses yang sesuai dengan sumbersumber dan layanan-layanan, serta munculnya partisipasi dalam kehidupan masyarakat, (2) pemberdayaan melalui aksi sosial dan politik, menekankan kepada pentingnya perjuangan dan perubahan politik untuk meningkatkan keberdayaan yang lebih efektif, dimana masyarakat dapat dilibatkan untuk melakukan aksi-aksi langsung. (3) pemberdayaan melalui pendidikan dan penyadaran, menekankan pada pentingnya proses pendidikan, sehingga pihak yang diberdayakan memperoleh kemampuan-kemampuan. Cara ini dilakukan dengan memberikan pengetahuan akan berbagai hal yang menjadi kendala baik struktural maupun kendala-kendala kemasyarakatan, juga memberikan keterampilan untuk berkarya secara efektif untuk menuju perubahan.

Dengan prinsip-prinsip yang telah dikemukakan tadi jika dapat diterapkan dalam upaya pemberdayaan masyarakat akan dapat berjalan dengan baik karena prinsip pemberdayaan adala merupakan proses kolaborasi antara pekerja sosial dan masyarakat sebagai yang diberdayakan, pemberdayaan menempatkan masyarakat sebagai subjek yang kompeten. Masyarakat harus mampu melihat dirinya sebagai agen penting yang dapat mempengaruhi perubahan dalam kelompok masyarakatnya.

Program Keaksaraan Fungsional (KF), mengatasi permasalahan yang terkait dengan pemberantasan buta aksara dan pemberian keterampilan bagi warga belajar atau peserta didiknya. Keaksaraan fungsional terdiri dari dua unsur, yaitu keaksaraan secara sederhana diartikan sebagai kemampuan untuk membaca, menulis, dan menghitung. Seseorang yang buta aksara adalah orang yang tidak dapat membaca, menulis dan berhitung dalam kehidupan sehari-hari. Seseorang yang melek huruf adalah orang yang dapat membaca maupun menulis kalimat sederhana dan berhitung. Sedangkan fungsional berkaitan erat dengan fungsi dan tujuan dilakukannya pembelajaran di dalam pendidikan keaksaraan, serta adanya jaminan bahwa hasil belajarnya benar-benar bermakna dan bermanfaat untuk meningkatkan mutu kehidupan. Fungsional juga bermakna warga belajar dapat memanfaatkan hasil belajarnya untuk memecahkan masalah-masalah yang berkaitan dengan keaksaraan yang ditemui dalam kehidupan sehari-hari. (Napitupulu,1998:4)

UNESCO mendefinisikan keberaksaraan sebagai "a continuum of learning that enables individuals to develop their knowledge and potential, pursue and achieve their goals, and participate fully in society" (Keberaksaraan merupakan kontinum pembelajaran sehingga individu-individu mampu mengembangkan pengetahuan dan potensi dirinya, mengejar dan mencapai tujuan yang ingin diraihnya, dan turut serta sepenuhnya dalam kegiatan masyarakat).

Kelompok belajar usaha adalah menumbuhkembangkan semangat berwirausaha bagi warga masyarakat yang tidak memiliki keterampilan tetapi mempunyai semangat untuk mengubah nasibnya dengan memanfaatkan peluang-peluang yang difasilitasi oleh pemerintah secara maksimal. Dengan semakin berkembangnya KBU diharapkan akan muncul para usahawan-usahawan kecil yang mampu meningkatkan taraf hidup di tingkat lokal dan bahkan nasional.

\section{METODE PENELITIAN}

Metode penelitian deskriptif kualitatif, penelitian ini lebih pada usaha untuk mengungkapkan fenomena dalam situasi sosial secara luas dan mendalam, meneliti pada kondisi objek yang alamiah dan peneliti sebagai instrumen kunci. Metode penelitian kualitatif (qualitative approach) 
ini, untuk mengkaji permasalahan dan memperoleh makna yang lebih mendalam di lokasi penelitian yang berkaitan dengan tingkah laku dan katakata responden khususnya dalam pemberdayaan masyarakat pasca keaksaraan fungsional melalui KBU untuk meningkatkan taraf hidup.

Subyek dalam penelitian ini adalah warga masyarakat Desa Cimenyan Kecamatan Cimenyan Kabupaten Bandung yang telah mengikuti program keaksaraan dasar. Warga belajar yang dijadikan subjek penelitian ini adalah ibu-ibu pasca Keaksaraan Fungsional (KF) yang baru membentuk kelompok belajar usaha. Jumlah populasi warga pasca keaksaraan fungsional 24 orang, subjek penelitian sebanyak 20 orang yang tergabung dalam KBU. Masyarakat pasca KF memiliki latar belakang pekerjaan buruh (tani musiman 8 orang, buruh serabutan 6 orang), pedagang asong 2 orang dan ibu rumah tangga 4 orang, waktu penelitian sejak bulan Maret hingga bulan Mei 2015.
Pengumpulan data observasi, wawancara dan dokumentasi yang dipandu oleh pedoman observasi, pedoman wawancara dan dokumentasi. Wawancara dilaksanakan dengan mendatangi ketua kelompok dan anggota masyarakat yang sedang dalam kelompok usahanya. Selain dengan warga belajar usaha, peneliti mewawancarai ketua PKBM sebagai penyelenggara KBU.

Untuk teknik pengumpulan data, peneliti menggunakan observasi partisipasif, wawancara mendalam, dokumentasi maupun diskusi kelompok terfokus (focus group discussion) untuk sumber data yang sama secara serempak.

Desain penelitian dengan urutan sebagai berikut: (1) mengumpulkan informasi, (2) mengajukan pertanyaan-pertanyaaan, (3) membangun kategorikategori, (4) mencari pola-pola (teori), dan (5) membangun sebuah teori atau membandingkan pola dengan teori-teori yang akhirnya memperoleh pemahaman baru. Desain penelitian dalam penelitian ini dapat dilihat berikut pada gambar 1 .

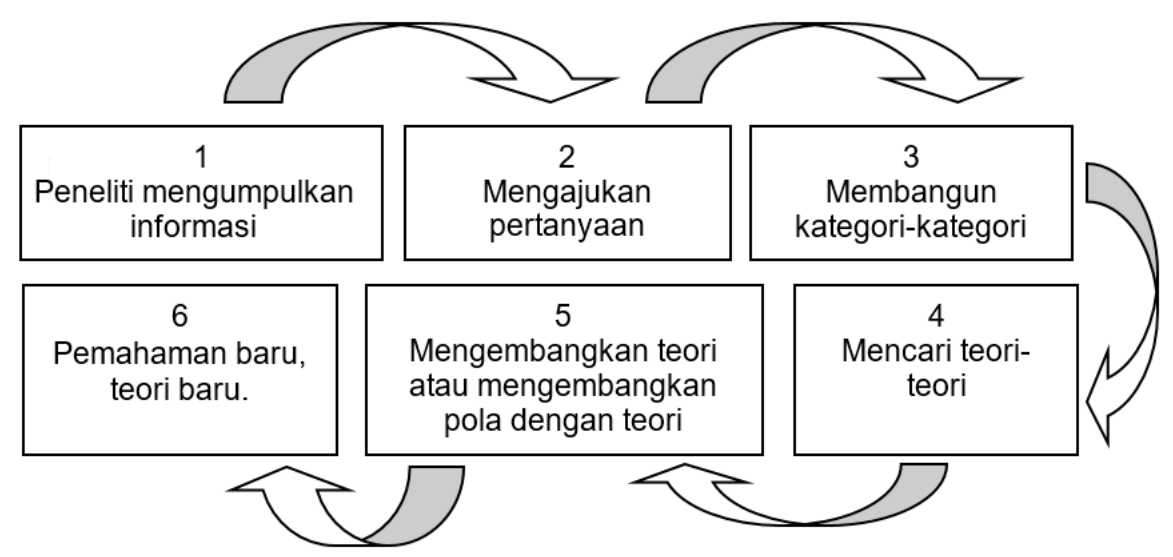

Gambar 1. Desain penelitian

Analisis data menggunakan analisis kualitatif yaitu dengan mendeskripsikan hasil observasi, wawancara dan dokumentasi. Untuk pengkajian atas data-data tertulis dengan teknik sampel bola salju (snowball sampling technique). Melalui teknik ini semua informasi dijaring sehingga bertambah dan berkembang terus sampai pada titik jenuh.
Langkah-langkah yang ditempuh untuk menganalisis data kualitatif pada tahap penelitian pendahuluan ini adalah: (a) reduksi data (data reduction), (b) penyajian data (data display), dan (b) penarikan kesimpulan dan verifikasi (conclusion drawing/verification).

\section{HASIL DAN PEMBAHASAN}

Observasi di lapangan, diperoleh kesan sejak masyarakat pasca KF membentuk KBU, belum juga menampakkan tanda-tanda perubahan sikap, maupun motivasi untuk mencoba melakukan aksi. Output terwujudnya keberdayaan masyarakat masih jauh dari harapan. Tingkat percaya diri masyarakat pasca KF rendah, nampak hanya berdiam diri atau malah ngobrol yang tidak ada manfaatnya.

Berdasarkan wawancara, sebagian 
kecil belum mengetahui manfaat program KF diikuti, setelah memperoleh selembar kertas yang bertulisan SUKMA, mereka merasakan kurang bermanfaat dalam kehidupan seharihari. Masyarakat yang mengetahui, kebanyakan menyadari bahwa keaksaraan fungsional merupakan kebutuhan, apalagi sekarang dibentuk kelompok belajar usaha (KBU). Usahanya dalam bidang masakan kuliner berbahan baku lokal. Responden mengatakan sangat bermanfaat, saya dapat membaca resep-resep masakan kuliner baru. Untuk memperkaya variasi resep-resep masakan kuliner. Dapat membaca macam-macam resep yang baru baik dari majalah maupun koran yang tersedia di taman bacaan masyarakat.

Manfaat mengikuti KF, hasil identifikasi sebagian besar menyatakan bahwa setelah mengikuti KF dan membentuk KBU sangat bermanfaat dapat mengembangkan atau membuat resep masakan baru, semakin lancar pula dalam membaca, semakin mudah memperoleh informasi yang dibutuhkan. Dari 20 orang yang diwawancarai menyatakan memiliki kemauan dan kemampuan/ keberdayaannya dalam mengikuti KBU, dengan beberapa alternatif jawaban kebermanfaatanya telah memiliki ijasah SUKMA sebagaimana yang tercantum pada tabel 1 .

Tabel 1. Pernyataan Masyarakat tentang Manfaat $\mathrm{KF}$

\begin{tabular}{|c|c|c|c|c|c|}
\hline \multirow{2}{*}{$\begin{array}{l}\text { Latar Belakang } \\
\text { Pekerjaan }\end{array}$} & \multicolumn{4}{|c|}{ Pernyataan } & \multirow{2}{*}{$\mathrm{Jml}$} \\
\hline & 1 & 2 & 3 & 4 & \\
\hline Buruh tani musiman & - & 1 & 4 & 3 & 8 \\
\hline buruh serabutan & - & - & 3 & 3 & 6 \\
\hline Pedagang asong & - & - & 1 & 1 & 2 \\
\hline Ibu rumah tangga & - & 1 & 1 & 2 & 4 \\
\hline Jumlah & - & 2 & 9 & 9 & 20 \\
\hline $\begin{array}{l}\text { Keterangan: } \\
1=\text { tidak bermanfaat } \\
2=\text { kurang manfaat }\end{array}$ & \multicolumn{4}{|c|}{$\begin{array}{l}3=\text { manfaat } \\
4=\text { sangat manfaat }\end{array}$} & \\
\hline
\end{tabular}

Berdasarkan data pada tabel 1 terlihat bahwa dari 20 orang yang berhasil diwawancarai, hanya ada 2 orang yang menyatakan bahwa pasca KF kurang bermanfaat dalam KBU, sedangkan 9 orang menyatakan pasca KF bermanfaat dalam $\mathrm{KBU}$, dan 9 orang lagi menyatakan pasca KF sangat bermanfaat dalam KBU. Berdasarkan hasil analisis tersebut nampak sebagian besar menyatakan bahwa pasca keaksaraan fungsional besar manfaatnya dalam kelompok belajar usaha.

Kegiatan kelompok belajar usaha fasilitator lebih banyak menggunakan pendekatan orang dewasa, responden merasa pendapat, ide dan lainnya dihargai. Fasilitator memotivasi bahwa masyarakat memiliki potensi, dengan demikian masyarakat memiliki kekuatan/berdaya untuk berusaha, dan percaya diri. Penuturan reponden dengan metode diskusi, tanya jawab suasana kekeluargaan menjadikan KBU nyaman dan harmonis.

Untuk mengetahui permasalahan yang dihadapi dalam pemberdayaan masyarakat setidaknya terdapat tiga aspek penting yang akan dilihat, yaitu gambaran pemberdayaan, ketercapaian, dan dampak pemberdayaan masyarakat pasca keaksaraan fungsional melalui KBU untuk meningkatkan taraf hidup.

Pertama, gambaran pemberdayaan masyarakat pasca keaksaraan fungsional melalui KBU untuk meningkatkan taraf hidup. Pemberdayaan masyarakat pasca keaksaraan fungsional di Desa Cimenyan pada awalnya memang mengalami kendala seperti kesadaran pada dirinya atau percaya dirinya kurang sehingga masyarakat tidak mampu melakukan kegiatan. Ketika masyarakat dibina untuk membuat KBU, masyarakat tidak memiliki keyakinan akan kemampuan pada diri sendiri. Proses pemberdayaan yang sangat diutamakan adalah untuk mengembangkan kesadaran dan potensi yang dimi-liki oleh manusia, sehingga manusia tersebut dapat dan siap untuk melakukan atau tidak melakukan suatu kegiatan. Untuk selanjutnya perlu menumbuhkan rasa percaya diri dan dikembangkannya kemampuan yang telah ada pada dirinya. Langkah berikutnya adalah menumbuhkan keyakinan dalam diri (manusia itu sendiri) untuk melakukan kegiatan atau tindakan, belajar dan melatih keterampilan yang dibutuhkannya untuk keperluan hidupnya. Jumlah masyarakat pasca KF 20 orang yang tergabung dalam KBU, selebihnya kembali pada kehidupan sehari-hari, mereka beranggapan bahwa KF tidak ada manfaatnya dalam kehidupan sehari-hari, hanya membuang-buang waktu saja.

Sasaran pemberdayaan masyarakat KF memang orang dewasa, dimana orang dewasa termotivasi untuk belajar karena mereka mengalami kebutuhan dan kepentingan bahwa belajar akan 
memuaskan, hal ini merupakan titik awal yang tepat untuk mengatur kegiatan pembelajaran orang dewasa. Orientasi orang dewasa untuk belajar adalah hidup yang berpusat; oleh karena itu, unit yang sesuai untuk mengorganisir pembelajaran orang dewasa adalah situasi hidup, bukan mata pelajarannya; pe-ngalaman orang dewasa merupakan sumber daya terkaya untuk belajar bagi orang dewasa, karena itu, metodologi inti dari pendidikan orang dewasa adalah analisis pengalaman. Orang dewasa memiliki kebutuhan yang mendalam untuk mengarahkan diri, mengendalihan emosi dirinya, maka keterlibatan tutor diperlukan dalam proses pembelajaran orang dewasa. Hal ini sesuai dengan pendapat Knowles (2005:40), bahwa (a) adults are motivated to learn as they experience needs and interests that learning will satisfy, (b) adults' orientation to learning is life-centered, (c) experience is the richest source for adult's learning, (d) adults have a deep need to be self-directing, dan (e) individual differences among people increase with age.

Kedua, ketercapaian pemberdayaan masyarakat pasca keaksaraan fungsional melalui KBU untuk meningkatkan taraf hidup. Berjalannya waktu masyarakat telah memiliki kelompok belajar usaha, dengan membentuk kelompok kecil sebanyak empat kelompok dengan anggota 5 orang/kelompoknya. Kelompok belajar usaha ini berupa masakan kuliner berbahan baku lokal yaitu singkong. Kerja keras untuk dapat mencapai kemandirian usaha. Masyarakat proaktif, yaitu selalu ada inisiatif, kerja keras dan tegas dalam melaksanakan tugas yang menjadi tanggung jawabnya. Suryana (2006:66) menyatakan: Untuk mencapai keberhasilan dan kemandirian usaha yang dimiliki sendiri, sangatlah tergantung pada: (1) individual skill and attitudes, (2) knowledge of business, (3) establishment of goal, (4) take advantage of the opportunities, (5) adapt to change, and, (6) minimize the threats to business. Kelompok belajar. Masyarakat pasca KF berangsur-angsur memiliki keterampilan, pengetahuan bisnis, dapat meminimalir hambatan berbisnis.

Pada setiap proses pemberdayaan dituntut penguatan masyarakat dalam peningkatan kapasitas, kemandirian dan kreatifitas mengelola berbagai kegiatan produktif (Santosa.I, dkk.,2012).
Pelaksanaan proses pemberdayaan masyarakat desa tidak dapat dilakukan secara temporal namun perlu berkelanjutan. Pemberdayaan masyarakat berbasis muatan lokal, pada dasarnya pemberdayaan masyarakat dapat berdaya dengan dukungan muatan lokal atau sumber daya alam seperti: lingkungan yang subur, tanaman singkong, ternak kambing dan sebagainya. Hasil tani dapat di olah menjadi barang setengah jadi atau bahkan menjadi barang siap konsumsi. Barang yang semula tidak bernilai menjadi bernilai, dari yang tidak memerlukan sumber daya manusia menjadi membutuhkan. Sependapat, (Wahyudin.U; 2012: 64): keberdayaan masyarakat miskin di pedesaan akan bertambah kuat dengan cara menciptakan perubahan kreatif yang berarti dari tidak bernilai menjadi bernilai, menghasilkan sebuah produk akhir yang memiliki nilai pasar, mampu memulai dari nol dan yang dianggap tidak berharga.

Ketiga, dampak pemberdayaan masyarakat pasca keaksaraan fungsional melalui KBU untuk meningkatkan taraf hidup; menghadapi permasalah usahanya, mampu berembug/ diskusi dengan bekal pengalamannya selama mengikuti KF, masyarakat merasakan manfaat dari KF; menyadari akan pentingnya informasi, pengetahuan, keterampilan dan sikap dalam dalam kehidupan; serta menyadari sebagai kebutuhan untuk tetap belajar.

Dampak KF pada individu memperoleh penghasilan tambahan, bahkan ada yang semula tidak punya pendapatan, kini punya pendapatan. Ketercapaian pemberdayaan masyarakat bukan saja berdampak pada individu, tetapi pada kelompok bahkan pada masyarakat secara umum. Secara internal keberdayaan masyarakat dipengaruhi oleh individu, seperti; melek huruf/ berpendidikan, toleransi, nilai-nilai, pendidikan maupun pengalaman. Sedangkan faktor yang berasal dari luar individu seperti model peran, aktivitas dan peluang. Oleh karena itu, inovasi dapat berkembang menjadi usaha mandiri melalui proses yang panjang, dan dipengaruhi oleh faktor lingkungan, organisasi dan keluarga.

Dampak perubahan sosial yang menyangkut kedekatan atau hubungan antara lapisan sosial yang dicirikan dengan adanya gerakan/perubahan ekonomi, maka kemampuan individu "senasib" untuk saling berkumpul dalam suatu kelompok 
cenderung dinilai sebagai bentuk pemberdayaan yang paling efektif. Hal tersebut dicapai melalui proses dialog dan diskusi di dalam kelompoknya, yaitu individu dalam kelompok belajar usaha untuk mendiskripsikan suatu situasi, kondisi kelompoknya, mendiskripsikan permasalahan yang terjadi dalam kelompok untuk selanjutnya mencari solusi.

Dampak lain dari pemberdayaan masyarakat $\mathrm{KF}$ melalui KBU (a) meningkatnya kemampuan anggota KBU di dalam memenuhi kebutuhan- kebutuhan hidup sehari-hari, ditandai dengan meningkatnya pendapatan, meningkatkan kualitas pangan, sandang, kesehatan dan tingkat pendidikan; (b) meningkatnya kemampuan anggota KBU dalam mengatasi masalah-masalah yang mungkin terjadi dalam keluarganya maupun dalam lingkungan sosial; (c) meningkatnya kemampuan anggota kelompok KBU dalam menampilkan peranan-peranan sosialnya. Keberdayaan ini tampak dalam sikap mental kewirausahaan dan kemandirian.

\section{PENUTUP}

\section{Kesimpulan}

Kelompok belajar usaha telah dibentuk masyarakat pasca keaksaraan fungsional di Desa Cimenyan, Kecamatan Cimenyan Kabupaten Bandung. Hasil kelompok belajar usaha memberikan keberdayaan masyarakat dalam meningkatkan taraf hidup. Pembentukan kelompok belajar usaha, masyarakat memiliki keberdayaan berusaha, memiliki keberanian, dan kemampuan berusaha. Kelompok belajar usaha selain memberdayakan masyarakat dalam meningkatkan taraf hidup, kemampuan membaca, menulis dan berhitung semakin baik. Masyarakat yang belum atau tidak memiliki kelompok belajar usaha pasca keaksaraan fungsional, sebagian kembali tidak dapat membaca dan menulis. Secara rinci sebagai berikut.

Pertama, gambaran pemberdayaan masyarakat pasca keaksaraan fungsional melalui KBU untuk meningkatkan taraf hidup. Dengan pendekatan orang dewasa, masyarakat diakui keberadaanya sebagai orang yang memiliki potensi. Adanya perubahan sikap pada masyarakat KF setelah bergabung dengan KBU.
Kedua, ketercapaian pemberdayaan masyarakat pasca keaksaraan fungsional melalui KBU untuk meningkatkan taraf hidup. Masyarakat proaktif, yaitu selalu ada inisiatif, kerja keras dan tegas dalam melaksanakan tugas yang menjadi tanggung jawabnya.

Ketiga, dampak pemberdayaan masyarakat pasca keaksaraan fungsional melalui KBU untuk meningkatkan taraf hidup. Adanya perubahan sikap, perubahan sosial, meningkatnya pendapatan, meningkatkan kualitas pangan, sandang, kesehatan dan tingkat pendidikan.

\section{Saran}

Berdasarkan kesimpulan yang telah dikemukakan, berikut ini merupakan saran dari penelitian ini. Pertama, praktisi Pendidikan Non Formal, untuk memotivasi dan memberdayakan masyarakat yang memiliki SUKMA (Surat Keterangan Melek Aksara) dan belum memiliki pekerjaan agar tidak kembali buta aksara dengan membentuk kelompok belajar usaha. Kedua, pemerintah daerah dan Instansi yang terkait mencarikan mitra usaha, memberi dukungan nyata berupa modal usaha, untuk keberlangsungan usahanya.

\section{DAFTAR PUSTAKA}

BPS. (2012). Persentase penduduk berumur 10 tahun ke atas yang buta huruf menurut Provinsi dan jenis kelamin 2009-2013. Jakarta: Badan Pusat Statistik.

Ife, J.,\&Tesoriero, F. (2008). Community development. Yogyakarta: Pustaka Belajar.

Knowles, M. S. (2005). The adult learnner, the definitive classic in adult education and human resource development. Tokyo: Elsevier Inc. Butterworth-Heinemann.
Napitupulu, W. P. (1999). Pendidikan dasar untuk pemberdayaan orang miskin. Diterjemahkan oleh Prem L. Kasaju dan C. Seshadri. Jakarta: UNESCO dan Ditjen Diklusepora Depdiknas.

Santosa, I.\& Rawuh E. (2012). Diseminasi model pemberdayaan masyarakat desa melalui pengelolaan agrowisata. Jurnal Mimbar, 28, (2), hlm 181-190.

Suharto, E. (2010). Membangun masyarakat memberdayakan rakyat. Bandung: refika 
Pemberdayaan Masyarakat Pasca ...

\section{Aditama}

Suryana. (2006). Kewirausahaan pedoman praktis, kiat dan proses menuju sukses. Jakarta: Salemba Empat
Wahyudin, U. (2012). Pelatihan kewirausahaan berlatar ekokultural untuk pemberdayaan masyarakat miskin pedesaan. Jurnal Mimbar XXVIII, (1), hIm 55-64. 